\title{
THE ANALYSIS OF ANTIBIOTIC CONSUMPTION AND BACTERIAL RESISTANCE AS AN INDICATOR OF THEIR PROPER USE AT THE UROLOGY DEPARTMENT IN THE HEALTH CENTRE "STUDENICA" KRALJEVO
}

\author{
Andriana Bukonjić ${ }^{1}$, Srđan Stefanović ${ }^{2}$
}

${ }^{1}$ Faculty of Medical Sciences, University of Kragujevac, Kragujevac

${ }^{2}$ Department of Pharmacology, Faculty of Medical Sciences, University of Kragujevac, Kragujevac

\author{
ANALIZA POTROŠNJE ANTIBIOTIKA I BAKTERIJSIKE \\ REZISTENCIJE KAO INDIKATORA NJIHOVE RACIONALNE UPOTREBE \\ NA ODELJENJU UROLOGIJE \\ ZDRAVSTVENOG CENTRA "STUDENICA" U KRALJEVU \\ Andriana Bukonjić1 ${ }^{1}$ Srđan Stefanović ${ }^{2}$ \\ Fakultet medicinskih nauka, Univerzitet u Kragujevcu, Kragujevac
}

Odsek za farmaciju, Fakultet medicinskih nauka, Univerzitet u Kragujevcu, Kragujevac

Received / Primljen: 07. 04. 2014.

Accepted / Prihvaćen: 01. 10. 2014.

\begin{abstract}
The objective of the study was to analyze antibiotic consumption and determine bacterial resistance rates as an indicator of the rational utilization of this drug group at the urology department in the Health Centre "Studenica" Kraljevo.

Over a two-year period, the average antibiotic consumption was 104.55 DDD/100BD. Of the total financial assets used for medical treatment, the antibiotic group JO1 had a share of 49.52\% in 2011 and 47.53\% in 2012. Antibacterial drugs from a group of $\beta$-lactamic antibiotics were consumed most commonly, at 54.02\% (2011) and 43.44\% (2012). Firstgeneration cephalosporins, quinolones and aminoglycosides were the most frequently used drug groups, while cephalexin was the antibiotic with the highest individual consumption. E. coli was the most frequently isolated bacterium in 2011, while in 2012, Klebsiella pneumoniae was the most frequently isolated bacterium. The total bacterial resistance both in 2011 and 2012 was above 50\%. Gram-negative bacteria showed a higher resistance rate (2011, 59.3\%; 2012, 58.9\%) than Grampositive bacteria (2011, 44.4\%; 2012, 40.6\%). Klebsiella pneumoniae was the bacterium with the highest resistance (75.3\%) in 2011, while in 2012, there was a resistance increase in Pseudomonas aeruginosa (71.4\%), especially to carbapenems. A correlation was determined between the consumption of individual antibiotics and bacterial strain resistance in 2011 $(r=0.433, p=0.044)$ and in $2012(r=0.478, p=0.024)$.

The high resistance rate shown in the bacterial strains, which was correlated with antibiotic consumption, as well as the great financial assets used for this group of drugs suggest the necessity for the rationalization of their utilization. Empirical therapy with Gram-negative bacteria should be based on carbapenems utilization, except with Pseudomonas aeruginosa, where piperacillin/tazobactam should be used.
\end{abstract}

Key words: antibiotics, bacterial resistance, DDD methodology, urology departments.

\section{SAŽETAK}

Cilj ovog istraživanja je analiza potrošnje antibiotika $i$ utvrđivanje stepena rezistencije bakterijskih sojeva kao indikatora racionalne primene ove grupe lekova na odeljenju urologije Zdravstvenog centra "Studenica" u Kraljevu.

$U$ toku dvogodišnjeg perioda prosečna potrošnja antibiotika iznosila je 104,55 DDD/100BD. Od ukupnih novčanih sredstava utrošenih za medikamentoznu terapiju na antibiotike grupe J01 izdvojeno je 49,52\% u 2011. odnosno 47,53\% y 2012. Antibakterijski lekovi iz grupe $\beta$-laktamskih antibiotika beleže najveći udeo u potrošnji sa 54,02\% (2011) $i$ 43,44\% (2012). Cefalosporini prve generacije, hinolonski antibiotici i aminoglikozidi su najčešće korišćene grupe antibiotika, a cefaleksin je antibiotik sa najvećom pojedinačnom potrošnjom. E. Coli je bila najčešće izolovana bakterija u 2011, dok je u 2012. Klebsiella pneumoni bila najzastupljenija. Ukupna rezistencija bakterijskih sojeva je u 2011. $i$ u 2012. bila veća od 50\%. Gram negativne bakterije su pokazale veći stepen rezistencije (2011-59,3\%, 2012- 58,9\%) u odnosu na Gram pozitivne (2011-44,4\%, 2012-40,6\%). Klebsiella pneumoni je bakterija sa najvećom rezistencijom u 2011. (75,3\%), dok se u 2012. beleži porast rezistencije Pseudomonas aeruginosa (71,4\%), posebno na karbapeneme. Utvrđena je korelacija potrošnje pojedinačnih antibiotika $i$ rezistencije bakterijskih sojeva u 2011. $(r=0,433, p=0,044) i$ 2012. $(r=0,478, p=0,024)$.

Visok nivo rezistencije koji pokazuju bakterijski sojevi, a koji je u korelaciji sa potrošnjom antibiotika, kao i velika novčana sredstva koja se izdvajaju za ovu grupu lekova, sugerišu na potrebu racionalizacije njihove primene. Empirijka terapija kod Gram negativnih bakterija bi trebalo da se zasniva na primeni karbapenema, osim kod Pseudomonas aeruginosa gde prednost treba dati piperacilin/tazobaktamu.

Ključne reci: antibiotici, bakterijska rezistencija, DDD metodologija, urologija. 


\section{ABBREVIATIONS}

ATC - Anatomical Therapeutic Chemical;

DDD - defined daily dose;

WHO - World Health Organization; SPSS - Service Provisioning System Software;
BD - Bed-days;

ALIMS - Medicines and Medical Devices Agency

of Serbia;

INN - International Nonproprietary Names.

\section{INTRODUCTION}

The antibiotic share of a hospital's consumption of all prescribed drugs goes up to $30 \%$, which makes them one of the most frequently used groups of drugs $(1,2)$. This study showed that $22.9 \%$ of inpatients used at least one antibiotic. Of those patients, 5.1\% had two antibiotics included in the therapyand $1.1 \%$ used three antibiotics. With $37.4 \%$ of patients, antibiotic therapy was inappropriate because it was unjustified; the choice of antibiotic was wrong or there was a utilization mistake (2). Inappropriate antibiotic utilization is one of the main reasons for microorganism resistance which, aside from increasing hospitalized treatment costs, leads to more serious consequences, such as an increase in morbidity and mortality rates $(3,4)$. The utilization of amoxicillin/clavulanate and quinolones was more frequently inappropriate, while the utilization of small-therapeutic-amplitude penicillins, cephalosporins, meropenem, metronidazole, and rifampicin was significantly appropriate. The inadequacy of use was connected with both the type of antibiotic and the specialist department. Urology, nephrology, otolaryngology and geriatrics were the specialist departments with risk factors for inappropriate antibiotic utilization, while paediatrics was isolated because of a significantly high rate of adequate antibiotic use (2).

Approximately $56 \%$ of the hospitalized patients at the urology department used antibiotics. According to the study, the highest percentage of patients at a urology department that used antibiotics was recorded in Turkey (approximately 70\%), whereas in Hungary (49\%) and Germany (47\%), this number was statistically significantly lower (5), which suggests the important regional differences in the utilization of these drugs. A multicenter centre study conducted in European countries between 2003 and 2010 showed an antibiotic resistance increase in urologic patients. Imipenem was the only antibiotic whose resistance to the total bacterial spectrum was below 10\% (5). Escherichia coli, the most frequently isolated bacterium in urologic patients, had a significant resistance rate to ampicillin, amoxicillin + clavulanic acid and fluoroquinolones (6). Monitoring and analysis of antibiotic consumption are highly important for antibiotic use rationalization in urologic patients. Due to differences in demographic characteristics, this monitoring should be conducted at regional and local levels (6).

Taking into consideration the increased bacterial strain resistance isolated in urologic patients (5), the existence of risk for inadequate antibiotic use at the urology depart- ment (2) and the necessity for local analysis of antibiotic consumption (5), the aim of this paper was to:

- analyze the individual antibiotic presence at the urology department;

- determine the presence and resistance rate expressed by bacterial strains isolated from the clinical material of inpatients at this department;

- determine the correlation between antibiotic consumption and bacterial resistance rate; and

- compare the given results with the available results of similar studies in our country and region.

\section{MATERIAL AND METHODS}

This study was based on data collected in the Health Centre "Studenica" that provides primary health care at the Health Centre Kraljevo and secondary health care in the General Hospital Kraljevo. The General Hospital has 580 beds and provides secondary health care for approximately 250,000 patients.

In accordance with the Anatomical Therapeutic Chemical (ATC) Classification System, the analysis was conducted on the antibiotic groups for systemic use, J01, used between January 2011 and December 2012 at the urology department. The data concerning total patient number and average hospitalization length at the urology department were obtained from the planning and analysis department. The central pharmacy provided the data concerning antibiotic consumption at the urology department, while bacteriological analysis results of samples were obtained from The Institute of Public Health.

All antibiotics were classified according to the ATC Classification System and their generic names; their total consumption was calculated and presented in units of measurement (mg and ij) which were then presented in DDD per 100 bed-days (BD), using the ATC/DDD methodology of the World Health Organization (WHO) (8).

The sensitivity of all of the bacterial strains isolated from the clinical material of hospitalized patients was estimated by the disc-diffusion method on Mueller-Hinton Agar.

During the study, data on individual patients were not collected. Thus, it was determined that approval by the Ethical Committee was not necessary.

The collected data were statistically analyzed. The descriptive statistical data were expressed as a percentage or as the arithmetic mean with the standard deviation. The data distribution normality was checked by the Kolmogorov- 
Table 1: The systemic use of different pharmacotherapeutic groups of antibiotics in the department of urology.

\begin{tabular}{|c|c|c|c|c|c|}
\hline \multirow{2}{*}{ ATC $*$} & \multirow{2}{*}{ Pharmacotherapeutic group of antibiotics } & \multicolumn{2}{|l|}{2011} & \multicolumn{2}{|l|}{2012} \\
\hline & & DDD/100BD\# & $\%$ & DDD/100BD\# & $\%$ \\
\hline $\mathrm{J} 01 \mathrm{C}$ & Penicillins & 3.18 & 3.09 & 2.90 & 2.73 \\
\hline J01DB & Cephalosporins $1^{\text {st }}$ generation & 28.58 & 27.81 & 24.41 & 22.95 \\
\hline J01DC & Cephalosporins $2^{\text {nd }}$ generation & 15.21 & 14.80 & 7.10 & 6.68 \\
\hline J01DD & Cephalosporins $3^{\text {rd }}$ generation & 6.74 & 6.56 & 10.78 & 10.13 \\
\hline J01DE & Cephalosporins $4^{\text {th }}$ generation & 0.00 & 0.00 & 0.00 & 0.00 \\
\hline $\mathrm{J} 01 \mathrm{DH}$ & Carbapenems & 1.80 & 1.75 & 1.01 & 0.95 \\
\hline J01E & Sulfonamides & 1.81 & 1.76 & 11.23 & 10.56 \\
\hline $\mathrm{J} 01 \mathrm{~F}$ & Macrolides & 1.78 & 1.73 & 0.87 & 0.82 \\
\hline J01G & Aminoglycosides & 18.33 & 17.84 & 21.66 & 20.37 \\
\hline $\mathrm{J} 01 \mathrm{M}$ & Quinolones & 19.44 & 18.92 & 19.17 & 18.03 \\
\hline J01XA & Glycopeptides & 0.06 & 0.06 & 0.12 & 0.11 \\
\hline $\mathrm{J} 01 \mathrm{~A}$ & Tetracyclines & 0.07 & 0.07 & 0.47 & 0.44 \\
\hline J01XD & Imidazole derivatives & 5.67 & 5.52 & 6.63 & 6.23 \\
\hline $\mathrm{J} 01 \mathrm{~B}$ & Amphenicol & 0.09 & 0.09 & 0.00 & 0.00 \\
\hline & In total & 102.76 & 100 & 106.35 & 100 \\
\hline
\end{tabular}

*Anatomical Therapeutic Chemical; \# Defined daily dose/100 bed-days.

Smirnov and Shapiro-Wilk tests. Student's t-test i.e., and its non-parametric alternative, Mann-Whitney U test, were used for determining statistically significant differences between the values of two continuous variables. The comparison between categorical variables was conducted using the Chi-square test. The relationship between antibiotic consumption and bacterial resistance was determined using Pearson's correlation. A value of $\mathrm{p}<0.05$ was considered statistically significant. All statistical analyses were performed with the computer programme SPSS, version 18.

\section{RESULTS}

The urology department of the General Hospital Kraljevo has 22 beds. In 2011, there were 1484 hospitalized patients with an average hospitalization length of 4.83 days; therefore, the number of achieved bed-days was 7167 (BD). In 2012, there were 6326 bed-days. The number of hospitalized patients for this year was 1451, and the average hospitalization length was 4.36 days.

Of the total financial assets used for medical treatment in this department in 2011, antibiotics had a share of 49.52\%, while in 2012 that share was $47.53 \%$.

During this two-year period, the average antibiotic consumption was 104.55 DDD/100BD. The increase of total antibiotic consumption from 102.76 DDD/100BD in 2011 to $106.35 \mathrm{DDD} / 100 \mathrm{BD}$ in 2012 was not statistically significant $(\mathrm{p}=0.645, \mathrm{U}=81.000)$. Antibacterial drugs for systemic use that belonged to the $\beta$-lactamic group were consumed most frequently at: $54.02 \%$ (2011) and $43.44 \%$ (2012). The decreased consumption of $\beta$-lactamic antibiotics by slightly more than $10 \%$ was not statistically significant $(\mathrm{p}=0.781$, $\mathrm{t}=0.288$ ). The consumption of first-generation cephalosporins was the highest when compared to other drug groups. The second most frequently consumed antibiotic was quinolones in 2011, and aminoglycosides in 2012 (Table 1).

During the monitored period at the urology department, 24 generically different antibiotics were used. During

Table 2: Ranking of the antibiotics composing 90\% of the total DDDs prescribed in the department of urology.

\begin{tabular}{|c|c|c|c|c|c|}
\hline \multirow{2}{*}{$\mathbf{A T C}^{*}$} & \multirow{2}{*}{$\mathbf{I N N}^{¥}$} & \multicolumn{2}{|c|}{2011} & \multicolumn{2}{|c|}{2012} \\
\hline & & DDD/100BD ${ }^{*}$ & $\%$ & DDD/100BD ${ }^{*}$ & $\%$ \\
\hline J01DB01 & Cephalexin & 25.34 & 24.66 & 18.59 & 17.48 \\
\hline J01MA02 & Ciprofloxacin & 12.95 & 12.60 & 14.74 & 13.86 \\
\hline J01GB06 & Amikacin & 9.91 & 9.64 & 13.20 & 12.41 \\
\hline J01EE01 & Co-trimoxazole & 1 & 1 & 11.23 & 10.56 \\
\hline J01DD04 & Ceftriaxone & 6.25 & 6.08 & 10.43 & 9.81 \\
\hline J01GB03 & Gentamicin & 8.42 & 8.19 & 8.46 & 7.95 \\
\hline J01DC02 & Cefuroxime & 15.21 & 14.80 & 7.10 & 6.68 \\
\hline J01XD01, P01AB01 & Metronidazole & 5.67 & 5.52 & 6.63 & 6.23 \\
\hline J01MB04 & Pipemidic acid & 6.49 & 6.32 & 4.43 & 4.17 \\
\hline & In total & 90.24 & 87.82 & 90.38 & 89.15 \\
\hline
\end{tabular}

*Anatomical Therapeutic Chemical; \# Defined daily dose/100 bed-days; ¥ International Nonproprietary Names. 
Table 3: Resistance of all of the isolates to individual antibiotics in the department of urology.

\begin{tabular}{|c|c|c|}
\hline \multirow{2}{*}{ Antibiotics } & \multicolumn{2}{|c|}{ Resistance N (\%) } \\
\hline & 2011 & 2012 \\
\hline Amikacin & $105(57.1)$ & $63(57.8)$ \\
\hline Amoxicillin & $6(31.6)$ & $5(29.5)$ \\
\hline Amoxicillin/clavulanate & $81(54.7)$ & $39(40.2)$ \\
\hline Ampicillin & $142(78.9)$ & $73(70.2)$ \\
\hline Cefaclor & $4(40.0)$ & $2(20.0)$ \\
\hline Cefalexin & $9(64.3)$ & $17(53.1)$ \\
\hline Cefepime & $2(100)$ & $4(80.0)$ \\
\hline Cefixime & $101(67.3)$ & $58(64.4)$ \\
\hline Cefotaxime & 105 (66.9) & $57(65.5)$ \\
\hline Ceftazidime & $18(46.2)$ & $20(66.7)$ \\
\hline Cefrixsone & $7(70.0)$ & $13(76.5)$ \\
\hline Ciprofloxacin & $169(81.6)$ & $108(85.0)$ \\
\hline Erythromycin & $0(0.0)^{E}$ & $0(0.0)^{£}$ \\
\hline Fusidic acid & $1(100)$ & l \\
\hline Gentamicin & $140(71.4)$ & $79(66.4)$ \\
\hline Chloramphenicol & $1(50.0)$ & $1(33.3)$ \\
\hline Imipenem & $20(10.7)$ & $16(14.7)$ \\
\hline Meropenem & $17(9.1)$ & $17(15.3)$ \\
\hline Clindamycin & $0(0.0)^{£}$ & I \\
\hline Nalidixic acid & / & $0(0.0)^{ \pm}$ \\
\hline Norfloxacin & $170(75.9)$ & $105(77.2)$ \\
\hline Ofloxacin & $108(68.4)$ & $52(71.2)$ \\
\hline Penicillin G & $8(30.8)$ & $9(33.3)$ \\
\hline Pipemidic acid & I & $18(75.0)$ \\
\hline Piperacillin & $127(73.8)$ & $69(70.4)$ \\
\hline Piperacillin/tazobactam & $12(22.6)$ & $12(35.3)$ \\
\hline Tetracycline & $16(69.6)$ & $13(76.5)$ \\
\hline Co-trimoxazole & $8(57.1)$ & $18(60.0)$ \\
\hline Vancomycin & $0(0.0)$ & $0(0.0)$ \\
\hline Ertapenem & $0(0.0$ & I \\
\hline In total & $1377(57.8)$ & $868(56.6)$ \\
\hline
\end{tabular}

$£$ One to two probes

both years, the same antibiotics comprised $90 \%$ of the total antibacterial drugs for systemic use, except cotrimoxazole, which was not included in 2011. Cephalexin was the antibiotic with the highest individual consumption (Table 2).

The total bacterial resistance was higher than $50 \%$ both in 2011 and in 2012. Table 3 shows the resistance for each individual antibiotic.

In 2011, 218 isolates (urine, 98.6\%) from the urology department were analyzed. Twenty different species of bacteria were isolated; two bacteria were isolated from each of 13 isolates. Escherichia coli was the most frequently isolated bacterium. In 2012, 141 isolates (urine, 98.7\%) were processed. Two bacteria were isolated from each of 9 isolates. Klebsiella pneumoniae was the most frequently isolated from 14 different isolated species of bacteria.

Gram-negative bacteria showed a higher resistance (2011, 59.3\%; 2012, 58.9\%) rate than Gram-positive bacteria $(2011,44.4 \%$; 2012, 40.6\%). The lowest level of Gramnegative bacterial resistance was to carbapenems, whereas Gram-positive bacteria were sensitive to glycopeptide antibiotics. Table 4 shows the resistance of the most frequently isolated bacteria.

There was a correlation between the consumption of individual antibiotics and bacterial strain resistance in $2011(\mathrm{r}=0.433, \mathrm{p}=0.044)$ and in $2012(\mathrm{r}=0.478, \mathrm{p}=0.024)$. There was no statistically significant correlation between antibiotic consumption during 2011 and bacterial resistance in $2012(\mathrm{r}=0.367, \mathrm{p}=0.093)$.

\section{DISCUSSION}

One of the main objectives of the study was to determine which antibiotics were used most commonly at the urology department and whether their consumption correlated significantly with bacterial strain resistance rates.

The consumption of all antibiotics for systemic use was analyzed up to level five of the ATC/DDD classification, and then, a comparison was performed. All antibiotics used at the urology department and included in the study belonged to group J01, except metronidazole for oral use, as it belongs to group $\mathrm{P}$ (antiparasitic products). The average antibiotic consumption during the two-year period was $104.55 \mathrm{DDD} / 100 \mathrm{BD}$, which was significantly lower than consumption at the urology departments of the Surgical Clinics in Niš and Novi Sad. The results of a two month study in 2004 showed that the consumption of group J anti-infective drugs at the urology department was 263.54 DDD/100BD in Niš and 224.85 DDD/100BD in Novi Sad (9). Lower antibiotic utilization at the urology department in Kraljevo compared with antibiotic utilization in Niš and Novi Sad was evident, even though our study included only J01 antibiotics because they were consumed the most frequently consumed antibiotic from group J (10). The average consumption of antibiotics for systemic use at the Surgical Clinic of Clinical Hospital Centre - Priština in Gračanica from 2007 to 2008 was 124.22 DDD/100BD (11), which was closer to the results of our study than to the study conducted in Niš and Novi Sad (9). According to our data, cephalosporins, quinolones and aminoglycosides had the highest utilization. In Niš and Novi Sad, cotrimoxazole had the highest consumption, followed by quinolones and aminoglycosides in Niš and cephalosporins and aminoglycosides in Novi Sad (9). The study of the Medicines and Medical Devices Agency of Serbia (ALIMS) showed that from 2004 to 2006 in health institutions in Serbia, penicillin with an extended spectrum (J01CA) was consumed 
Table 4: Resistance within the most frequently isolated bacteria.

\begin{tabular}{|c|c|c|c|c|c|c|c|c|}
\hline \multirow{3}{*}{ Antibiotics } & \multicolumn{8}{|c|}{ Resistance N (\%) } \\
\hline & \multicolumn{2}{|c|}{$\begin{array}{l}\text { Escherichia } \\
\text { coli }\end{array}$} & \multicolumn{2}{|c|}{$\begin{array}{c}\text { Klebsiella } \\
\text { pneumoniae }\end{array}$} & \multicolumn{2}{|c|}{$\begin{array}{l}\text { Proteus } \\
\text { mirabilis }\end{array}$} & \multicolumn{2}{|c|}{ Pseudomonas aeruginosa } \\
\hline & 2011 & 2012 & 2011 & 2012 & 2011 & 2012 & 2011 & 2012 \\
\hline Amikacin & $9(28.1)$ & $2(12.5)$ & $24(64.9)$ & $16(43.2)$ & $14(53.8)$ & $16(72.7)$ & $27(71.1)$ & $25(86.2)$ \\
\hline Amoxicillin & 1 & $0(0.0)^{ \pm}$ & 1 & 1 & 1 & 1 & 1 & 1 \\
\hline Amoxicillin/clavulanate & $5(20.8)$ & $1(5.9)$ & $23(63.9)$ & $17(45.9)$ & $18(72.0)$ & $17(70.8)$ & $4(100)$ & $1(100)$ \\
\hline Ampicillin & $27(69.2)$ & $15(68.2)$ & $39(100)$ & $29(93.5)$ & $26(86.7)$ & $18(81.8)$ & $3(100)$ & $2(100)$ \\
\hline Cefalexin & $1(50.0)$ & $2(28.6)$ & 1 & $7(100)$ & $0(0.0)^{£}$ & $3(75.0)$ & 1 & 1 \\
\hline Cefepime & 1 & 1 & 1 & $0(0.0)^{£}$ & 1 & I & & $2(100)$ \\
\hline Cefaclor & 1 & $1(100)$ & 1 & 1 & 1 & 1 & & 1 \\
\hline Cefixime & $6(16.2)$ & $4(17.4)$ & $36(94.7)$ & $32(84.2)$ & $20(69.0)$ & $19(76.0)$ & 4. (100) & $1(100)$ \\
\hline Cefotaxime & $6(15.8)$ & $2(10.0)$ & $37(94.9)$ & $29(90.6)$ & $18(64.3)$ & $17(73.9)$ & 4. (100) & $1(33.3)$ \\
\hline Cefriaxone & $0(0.0)^{£}$ & $1(33.3)$ & $1(100)$ & $5(100)$ & $0(0.0)^{ \pm}$ & $1(33.3)$ & 1 & 1 \\
\hline Ceftazidime & 1 & 1 & 1 & 1 & 1 & 1 & $15(45.5)$ & $17(63.0)$ \\
\hline Ciprofloxacin & $14(42.4)$ & $9(52.9)$ & $38(100)$ & $33(89.2)$ & $20(76.9)$ & $19(86.4)$ & $35(94.6)$ & $30(100)$ \\
\hline Fusidic acid & $1(100)$ & 1 & 1 & 1 & 1 & 1 & 1 & 1 \\
\hline Gentamicin & $15(35.7)$ & $4(17.4)$ & $32(84.2)$ & $26(74.3)$ & $16(57.1)$ & $16(64.0)$ & $32(91.4)$ & $27(96.4)$ \\
\hline Chloramphenicol & 1 & 1 & 1 & 1 & 1 & $1(100)$ & $1(100)$ & 1 \\
\hline Imipenem & $0(0.0)$ & $0(0.0)$ & $2(5.3)$ & $0(0)$ & $3(11.5)$ & $0(0)$ & $11(28.2)$ & $15(50.0)$ \\
\hline Meropenem & $0(0.0)$ & $0(0.0)$ & $2(5.3)$ & $0(0)$ & $0(0.0)$ & $0(0)$ & $11(28.9)$ & $14(48.3)$ \\
\hline Ofloxacin & $12(30.0)$ & $8(44.4)$ & 37 (94.9) & $27(96.4)$ & $19(70.4)$ & $15(75.0)$ & $5(83.3)$ & $1(100)$ \\
\hline Norfloxacin & $14(33.3)$ & $10(41.7)$ & $38(97.4)$ & $34(89.5)$ & $20(69.0)$ & $18(75.0)$ & $35(94.6)$ & $28(100)$ \\
\hline Nalidixic acid & 1 & $0(0.0)^{£}$ & 1 & 1 & 1 & 1 & 1 & 1 \\
\hline Piperacillin & $13(59.1)$ & $5(38.5)$ & $35(97.2)$ & $26(92.9)$ & $20(83.3)$ & $16(80.0)$ & $23(63.9)$ & $18(60.0)$ \\
\hline Penicillin G & 1 & $0(0.0)^{£}$ & / & 1 & 1 & 1 & 1 & 1 \\
\hline Pipemidic acid & 1 & $4(57.1)$ & 1 & $10(83.3)$ & 1 & $4(80.0)$ & 1 & 1 \\
\hline Piperacillin/tazobactam & $0(0.0)$ & / & $1(50.0)$ & 1 & $1(50.0)$ & / & $8(23.5)$ & $10(35.7)$ \\
\hline Tetracycline & $0(0.0)^{£}$ & $1(25.0)$ & 1 & $0(0.0)$ & 1 & $0(0.0)^{£}$ & / & 1 \\
\hline Co-trimoxazole & $1(50.0)$ & $2(25.0)$ & 1 & $8(80.0)$ & $2(66.7)$ & $5(83.3)$ & 1 & / \\
\hline Ertapenem & $0(0.0)^{ \pm}$ & 1 & 1 & 1 & 1 & 1 & 1 & 1 \\
\hline Vancomycin & 1 & $0(0.0)^{£}$ & & 1 & & 1 & & / \\
\hline In total & $124(29.2)$ & $\begin{array}{l}71 \\
(27.4)\end{array}$ & $345(75.3)$ & $299(65.7)$ & $197(59.5)$ & $185(63.1)$ & $218(62.5)$ & $192(71.4)$ \\
\hline $\begin{array}{l}\text { Frequently isolated } \\
\text { bacteria } \mathrm{N}(\%)\end{array}$ & 43 (18.6) & $25(16.7)$ & 39 (16.9) & $38(25.3)$ & $31(13.4)$ & $26(17.3)$ & $37(16.0)$ & $30(17.3)$ \\
\hline
\end{tabular}

${ }^{£}$ One to two probes

most frequently, followed by aminoglycosides and cephalosporins of the third and first generation (10). However, at the urology department of the Health Centre "Studenica" during 2011 and 2012, penicillin (J01C) consumption was only approximately $3 \%$ of total antibiotic consumption (Table 1). High consumption of this antibiotic group, as opposed to others from J01, was not recorded at the urology departments in Niš or Novi Sad (9).

In 2011 as well as 2012, cephalexin was the antibiotic consumed most frequently (Table 2). This antibiotic, according to the study by the ALIMS, was included in the ten most frequently used antibiotics in health institutions from 2004 to 2006, but it was not among the first three for its consumption (10). Based on the three-year study conducted in the Clinical Centre Niš, ceftriaxone had the highest consumption in 2003 and 2007, whereas in 2005, ampicillin and ciprofloxacin preceded it. Cephalexin was not among the ten most frequently used antibiotics for its consumption at the Clinical Centre Niš (12). At the Surgical Clinic of the Clinical Hospital Centre - Priština in Gračanica, cephalexin was the third most frequently consumed antibiotic in 2007, after cefuroxime and ceftriaxone, whereas in 2008, both cotrimoxazole and gentamicin had were consumed more than cephalexin (11).

According to our study, the average bacterial resistance both in 2011 and 2012 was above 50\% (Table 3). A high resistance rate $(70.3 \%)$ was also shown in a study that followed the prevalence and resistance rate of urinary tract infection agents in patients treated in the Clinical Centre Kragujevac from 2009 to 2011 (13). As expected, the resistance rate was positively correlated with antibiotic consumption. If we ignored antibiotics that had only one to 
two tests, the lowest resistance rate was for carbapenems and glycopeptide antibiotics, i.e., vancomycin. In Table 3, it can be observed that in 2011 there was lower resistance to meropenem and imipenem in 2012. However, both antibiotics had a tendency to increase resistance. The results showing a low resistance rate to vancomycin (Table 3) should be observed with caution because there were few tests of bacterial sensitivity for this antibiotic, and these tests were not conducted on the most frequently isolated bacteria (Table 4). The results of a multicentre study conducted in Europe showed that the resistance rate to all tested antibiotics, except imipenem, was above 10\% (6).

Our results showed that, of the four most frequently isolated bacteria, Escherichia coli had the lowest resistance rate in the monitored period. This bacterium showed the highest sensitivity to carbapenems and piperacillin/ tazobactam, which is in congruence with other studies (1214). If the number of tests was taken into consideration, Escherichia coli developed the highest resistance to ampicillin $(69.2 \%, 2011 ; 68.2 \%, 2012)$ (Table 4$)$. According to a study conducted in a tertiary care hospital in Spain, Escherichia coli resistance to ampicillin was $48.1 \%$ (7), whereas according to results from Iran, the resistance to the same antibiotic was $63.2 \%$ (14). Escherichia coli showed higher resistance to ampicillin in the Clinical Centre Kragujevac (13) than in the results of our study. The Escherichia coli resistance rate to ampicillin in the Clinical Centre Niš decreased in 2007 (57.61\%) as opposed to 2003 (73.08\%), but it still remained the antibiotic to which this bacterium showed the highest resistance (12).

In 2011, of all the most frequently isolated bacteria, Klebsiella pneumoniae showed the highest resistance, especially to quinolones and amikacin (Table 4). In a tenyear study, this bacterium showed a statistically significant increase in resistance to ceftadizime, ciprofloxacin and cotrimoxazole, whereas the sensitivity to carbapenems remained at a very high level (15), which was supported in our study.

In 2012, there was a resistance increase in Pseudomonas aeruginosa. The resistance increase of this bacterium to carbapenems presented a unique problem, which was also seen observed in other studies $(13,16,17)$. In our study, Pseudomonas aeruginosa had the highest sensitivity to piperacillin/tazobactam, which was in accordance with other studies (18).

\section{CONCLUSION}

According to the results of this study, antibiotic consumption (DDD/100BD) at the urology department of the Health Centre "Studenica" was lower than in other areas of the country (9). However, the high resistance rate that the bacterial strains showed, which was in correlation with antibiotic consumption, as well as the great financial assets used for this group of drugs, suggests the necessity for rationalization of their utilization. Gram-negative bacteria were more frequently isolated and had a higher resistance rate than Gram-positive bacteria. Empirical therapy with Gram-negative bacteria should be based on carbapenem utilization, except with Pseudomonas aeruginosa, where piperacillin/tazobactam should be used. When choosing antibiotics, empirically or based on the results of an antibiogram, one should consider both pharmacokinetic and pharmacodynamic drug characteristics, individual patient characteristics, and the possibility of interactions with other drugs (19).

\section{ACKNOWLEDGEMENTS:}

The authors would like to thank the personnel of the General Hospital in Kraljevo for providing assistance and sharing their annual reports.

\section{REFERENCES}

1. Vlahović-Palcevski V, Morović M, Palcevski G, BeticaRadić L. Antimicrobial utilization and bacterial resistance at three different hospitals. Eur J Epidemiol. 2001; 17(4): 375-83.

2. Willemsen I, Groenhuijzen A, Bogaers D, Stuurman A, van Keulen P, Kluytmans J. Appropriateness of antimicrobial therapy measured by repeated prevalence surveys. Antimicrob Agents Chemother. 2007; 51(3): 864-7.

3. Raymond DP, Pelletier SJ, Sawyer RG. Antibiotic utilization strategies to limit antimicrobial resistance. Semin Respir Crit Care Med 2002; 23(5): 497-501.

4. Urbánek K, Kolár M, Strojil J, Koukalová D, Cekanová L, Hejnar P. Utilization of fluoroquinolones and Escherichia coli resistance in urinary tract infection: inpatients and outpatients. Pharmacoepidemiol Drug Saf. 2005; 14(10): 741-5.

5. Johansen TE, Cek M, Naber KG, Stratchounski L, Svendsen MV, Tenke P; PEP and PEAP-study investigators; Board of the European Society of Infections in Urology. Hospital acquired urinary tract infections in urology departments: pathogens, susceptibility and use of antibiotics. Data from the PEP and PEAP-studies. Int J Antimicrob Agents. 2006; 28: S91-107.

6. Tandogdu Z, Cek M, Wagenlehner F, Naber K, Tenke P, van Ostrum E, Bjerklund, Johansen T. Resistance patterns of nosocomial urinary tract infections in urology departments: 8-year results of the global prevalence of infections in urology study. World J Urol. 2013. Epub ahead of print

7. Medina-Polo J, Jiménez-Alcaide E, García-González L, Guerrero-Ramos F, Pérez-Cadavid S, ArrébolaPajares A, Sopeña-Sutil R, Benítez-Salas R, DíazGonzález R, Tejido-Sánchez A. Healthcare-associated infections in a department of urology: Incidence and patterns of antibiotic resistance. Scand J Urol. 2013. Epub ahead of print 
8. World Health Organization Collaborating Centre for Drug Statistics Methodology. About the ATC/DDD system. (Available at: http://www.whocc.no/filearchive/ publications/1_2013guidelines.pdf Accessed 1.12.2013).

9. Pešić G, Jović Z, Vasić K. Primena ATC/DDD metodologije pri upoređivanju upotrebe antibiotika $u$ toku dvomesečnog perioda u dvema hirurškim bolnicama. Acta Facultatis Medicae Naissensis. 2006; 23(1): 39-44.

10. Radonjić V, Đukić L, Stefanović D, Tešić D. Promet i potrošnja antibiotika u Republici Srbiji. Arhiv za farmaciju. 2007; 57(4-5): 332-46.

11. Bulajić S, Hadžistević S, Milovanović D, Trajković G, Vujačić N, Stanojević Z. Upotreba antibiotika za sistemsku primenu u hirurškoj klinici KBC-Priština $\mathrm{u}$ Gračanici. Praxis medica. 2011; 39(1-2): 17-22.

12. Veliçković-Radovanović R, Petrović J, Kocić B, Antić S, Randelović G. Correlation between antibiotic consumption and bacterial resistance as quality indicator of proper use of these drugs in inpatients. Vojnosanit Pregl. 2009; 66(4): 307-12.

13. Pavlović R, Janković S, Đorđević Z. Profile of urinary tract infections pathogens and their antimicrobial resistance patterns during three-year period (2009-2011) in the Clinical center Kragujevac. Racionalna terapija 2013; 5(2): 27-41.
14. Ghadiri H, Vaez H, Khosravi S, Soleymani E. The antibiotic resistance profiles of bacterial strains isolated from patients with hospital-acquired bloodstream and urinary tract infections. Crit Care Res Pract. 2012; 2012: 890797.

15. Van der Donk CF, Beisser PS, Hoogkamp-Korstanje JA, Bruggeman CA, Stobberingh EE; Antibiotic Resistance Surveillance Group. A 12 year (1998-2009) antibiotic resistance surveillance of Klebsiella pneumoniae collected from intensive care and urology patients in 14 Dutch hospitals. J Antimicrob Chemother. 2011; 66(4): 855-8.

16. Zilberberg MD, Chen J, Mody SH, Ramsey AM, Shorr AF. Imipenem resistance of Pseudomonas in pneumonia: a systematic literature review. BMC Pulm Med 2010; 10: 45.

17. Lautenbach E, Synnestvedt M, Weiner MG, Bilker WB, Vo L, Schein J, Kim M. Imipenem resistance in Pseudomonas aeruginosa: emergence, epidemiology, and impact on clinical and economic outcomes. Infect Control Hosp Epidemiol. 2010; 31(1): 47-53.

18. Master RN, Clark RB, Karlowsky JA, Ramirez J, Bordon JM. Analysis of resistance, cross-resistance and antimicrobial combinations for Pseudomonas aeruginosa isolates from 1997 to 2009. Int J Antimicrob Agents. 2011; 38(4): 291-5.

19. Jankovic S. Rational Use Of Antibiotics In Clinical Practice. Racionalna terapija 2009; 1(1): 1-6. 